\title{
ANALISIS IMPLEMENTASI ALTERNATIF MODEL JUAL BELI PADA PRODUK JUAL BELI TANAH DENGAN HAK MEMBELI KEMBALI PADA PT AKUISINDO ASSETAMA JAKARTA DITINJAU DARI HUKUM POSITIF DAN SYARIAH
}

\author{
Bahori Ahoen \\ Pascasarjana TAZKIA, Magister Ekonomi, Islamic Bussiness Management \\ Orie_ahoen@yahoo.com
}

\begin{abstract}
This study aims to determine the implementation Sale and purchase On Selling Products Buy land with the Right to Buy Back at PT. Akuisindo Assetama Jakarta, in terms of positive law applicable in Indonesia and Sharia law,This study uses the approach of ANP, data obtained are of primary data in the form of questionnaires, transcripts of interviews with various respondents and secondary data from the study of literature and then the data is used for processing by the method of ANP, Research Reveals that of Four Product Type of sale with right to buy Back, namely the Sale and Purchase of Leases, is where the sale with repurchase by the addition of a lease contract, sale and purchase of a sale with repurchase with the release of the sale of the first and second, Ba'i Al-Wafa 'the use bai'wafa, and the use of contract Rahn Rahn.Fourth of the product type Buy Sell Rent where the sale with repurchase by the addition of a lease contract is a sale and purchase of the most consistent with the Sharia.
\end{abstract}

Keywords: Sale and purchase with the buy back Clause, Repo, Properti

Abstrak: Penelitian Ini bertujuan untuk mengetahui Implementasi Jual beli Pada Produk Jual Beli tanah dengan Hak Membeli Kembali di PT. Akuisindo Assetama Jakarta, ditinjau dari Hukum Positif yang berlaku di Indonesia dan Hukum Syariah, Penelitian ini menggunakan pendekatan ANP, Data yang didapatkan adalah data primer berupa isian kuesioner, transkrip wawancara dengan berbagai responden dan data sekunder dari telaah literature yang kemudian data tersebut digunakan untuk proses pengolahan dengan metode ANP, Hasil Penelitian Mengungkapkan bahwa dari Empat Jenis Produk jual beli dengan Hak membeli Kembali yaitu Jual Beli Sewa dimana jual-beli dengan hak membeli kembali dengan adanya tambahan akad sewa 
menyewa, Jual Beli yang merupakan jual-beli dengan hak membeli kembali dengan terlepasnya antara jual-beli pertama dan kedua, Ba'i Al-Wafa' yang menggunakan bai'wafa, dan Rahn yang menggunakan akad rahn. dari Keempat Jenis Produk tersebut Jual Beli Sewa dimana jual-beli dengan hak membeli kembali dengan adanya tambahan akad sewa menyewa adalah Jual beli yang paling bersesuaian dengan Syariah.

Kata Kunci: Jual beli tanah dengan hak membeli kembali, Repo, Properti.

\section{PENDAHULUAN}

Islam adalah agama yang mudah dan syamil (menyeluruh) meliputi segenap aspek kehidupan. Islam selalu memerhatikan berbagai maslahat dan menghilangkan segala bentuk madharat. Termasuk dalam maslahat tersebut adalah sesuatu yang Allah syariatkan dalam jual beli dengan berbagai aturan yang melindungi hak-hak pelaku bisnis dan memberikan berbagai kemudahan-kemudahan dalam pelaksanaannya. Selain membahas masalah ibadah-ibadah ritual yang bersifat mahdah, Islam juga membahas permasalahan jual beli secara mendetail. Islam tidak mengenal dikotomi antara aktivitas duniawi dengan ukhrawi. ${ }^{1}$

Jual beli inilah merupakan salah satu bentuk muamalah, yaitu hubungan yang terjadi antara manusia dengan manusia lainnya. Bentuk muamalah seperti jual beli ada karena didasarkan atas rasa saling membutuhkan. Hal ini penjual membutuhkan pembeli agar membeli barangnya sehingga memperoleh uang. Sedangkan pembeli melakukan jual beli untuk memperoleh barang yang dibutuhkan. Akibat dari saling membutuhkan ini maka rasa persaudaraan semakin meningkat. Menurut kaidah fiqh, prinsip dasar dalam transaksi muamalah dan persyaratannya yang terkait dengannya adalah boleh selama tidak dilarang oleh syariah atau bertentangan dengan dalil syariah sesuai dengan kaidah. ${ }^{2}$

Adapun rukun dan syarat-syarat jual beli secara umum ada tiga macam yaitu, ${ }^{3}$ Subyek akad, yaitu adanya penjual dan pembeli, yang kedua

\footnotetext{
${ }^{1}$ A. Karim, Adiwarman, Bank Islam: Analisis Fiqih dan Keuangan, Edisi 3. (Jakarta: PT. Raja Grafindo Persada, 2008) hal 87.

${ }^{2}$ Ali M. Daud, Hukum Islam: Pengantar Ilmu Hukum dan Tata HukumIslam di Indonesia. Ed 6. Cet 10.( Jakarta: Raja Grafindo Persada, 2002) hal 18.

${ }^{3}$ Sabiq, Sayyid, Fiqh Sunnah (jilid 2). (Bandung: al Maarif, 1987) hal 50.
} 
yaitu adanya sigat akad yaitu adanya ijab dan kabul diantara keduanya, dan obyek akad, yaitu obyek atau barang yang dijual oleh si penjual. Ijab dan kabul harus tertuju pada suatu objek yang merupakan obyek akad. ${ }^{4}$

Berkembangnya suatu zaman menjadikan jual beli semakin beraneka ragam. Salah satunya adalah bai' al-wafa'. Arti dari jual beli ini sendiri adalah jual beli yang dilangsungkan antara dua belah pihak, yang dibarengi dengan syarat bahwa barang yang dijual tersebut dapat dibeli kembali oleh penjual, apabila tenggang waktu yang ditentukan telah tiba. ${ }^{5}$

Memang jual beli semacam ini terbilang unik, bahkan di zaman Nabi jual beli semacam ini belum ada. Bai' al-wafa' baru dikenal sekitar pertengahan abad Ke-V H di Bukhara dan Balkhan. Ketika itu di tengahtengah masyarakat telah meluas sebuah kenyataan bahwa, si kaya yang mempunyai sejumlah uang tidak mau meminjamkan uangnya kepada orang yang membutuhkan (si miskin). Si kaya baru mau memberikan pinjaman uang, jika ia diberi hak untuk mengembangkan harta jaminannya. ${ }^{6}$

Jual beli dengan hak membeli kembali merupakan produk yang menjadi suatu pilihan tersendiri dalam melakukan transaksi muamalah, hal inilah yang mendorong PT Akuisindo Assetama menciptakan produk jual beli dengan hak membeli kembali, banyak hal yang menjadi dasar mengapa PT Akuisindo Assetama membuat produk tersebut, yang paling utama adalah untuk menghindari riba. ${ }^{7}$

PT. Akuisindo Assetama beralamat di Jalan TB Simatupang Kav. 41 Cilandak Jakarta Selatan di Ged. Baltway Lt. 5 Tower B adalah sebuah perusahaan yang bergerak di bidang Properti Jual Beli Sewa, PT. Akusindo juga dapat membantu masyarakat dengan keperluan dana cepat dengan menjual Propertinya dengan opsi dibeli kembali, dengan sistem ini PT Akuisindo melibatkan beberapa buyer-buyer atau Investor.

Allah menjelaskan bahwa menghalalkan jual beli dan mengharamkan riba, dan jual beli dengan hak membeli kembali merupakan opsi untuk

\footnotetext{
${ }^{4}$ Abdul Rasyid Saliman. et al. (2008). Hukum Bisnis Untuk Perusahaan: Teori dan Contoh Kasus, Kencana Prenada Media Group, cet. Ke 4.

${ }^{5}$ Nasrun Haroen, Fiqh Muamalah, (Jakarta: Gaya Media Pratama, 2007) Hal. 157

${ }^{6}$ Ahmad Azhar Basyir,Asas-asas Hukum Muamalah (Hukum Perdata Islam), (Yogyakarta: Perputakaan FH UII, 1993) Hal 65.

7 Abdurrahman al-Jaziri. (1990). Kitab al-Fiqh Ala Madzahib al-Arbaah, Juz I, Beirut: Daaral-Kutb al-Ilmiyyah,.
} 
menghindari praktek riba. ${ }^{8}$ Tetapi memang tidak bisa dipungkiri harus banyak hal yang harus dilakukan untuk mengenalkan produk jual beli dengan hak membeli kembali, karena tentunya sebagai perusahaan PT Akuisindo Assetama harus memperoleh keuntungan dan di sisi lain hal ini merupakan bentuk ibadah yang digunakan sebagai sarana tolong menolong.

\section{METODE PENELITIAN}

Penelitian ini menggunakan pendekatan ANP (Analytic Network Process) untuk mengetahui praktik implementasi dan legalitas jual-beli dengan hak membeli kembali. Data yang didapatkan adalah data primer berupa transkrip wawancara dengan berbagai responden yang kemudian data tersebut digunakan untuk proses pengolahan dengan metode ANP (Analytic Network Process) menggunakan data primer berupa isian kuesioner dan data sekunder dari telaah literatur.

Kerangka ANP (Analytic Network Process) yang telah disusun baru dapat diselesaikan setelah tersedia datamaupun informasi preferensi/ tanggapan/ pendapat yang diwakili oleh para pakar/ praktisi ekonomi Islam tentang permasalahan yang akan diteliti. Untuk memperoleh data preferensi tersebut, digunakan (kuesioner/ wawancara langsung) kepada para pakar dan praktisi. Pengumpulan data ini dititikberatkan bagi kalangan praktisi LKMS (Lembaga Keuangan Mikro Syariah) maupun pakar untuk mendapatkan datadata yang diperlukan untuk analisa kualitatif dalam kerangka analisis yang akan digunakan.

Adapun responden yang penulis lakukan wawancara dan indept interview adalah:

1. Bapak Muhammad Gunawan Yasni, S.E, Ak., MM,CIFA, FIIS Perwakilan Dewan Syariah Nasional Majelis Ulama Indonesia (DSN MUI).

2. Bapak Nurizal Ismail, Ph.D, Ketua Sekolah Tinggi Ekonomi Islam Husnayain Jakarta.

3. Bapak Imam Cahyono. S.H, Mkn. selaku Notaris dan PPAT di Kota Depok

4. Ibu Dian J Bintahir, General Manager PT Akusindo Assetama (Praktisi Bisnis Properti).

\footnotetext{
${ }^{8}$ Afifuddin dan Beni Ahmad Saebani. Metodologi Penelitian Kualitatif (Bandung: Graha Ilmu, 2000) 72
} 
5. Ibu Rahmatiyaningsih, M.E.Sy, Kepala Cabang BTN Syariah Kota Bogor. (Praktisi Pembiayaan Properti)

6. Dr. Misno, M.E.I, Kepala program Studi Muamalah STEI Tazkia

7. Mahbubi Ali, Ph.D, Dewan Pengawas Syariah pada Lembaga Keuangan Syariah AFFIN di Malaysia.

8. Abdul Mughni, B.A,M.E.I, Dewan Pengawas Syariah Bank Tegar Beriman dan Asuransi Syariah Mikro Indonesia.

9. H.Aristiawan Dwi Putranto. SH. M. Kn selaku Notaris dan PPAT di Matraman Jakarta Timur.

10. Nilam Purnamawaty Januarso, SH, selaku Notaris dan PPAT di Jakarta Barat.

11. Ibnu Hartawan selaku nasabah PT Akusindo Assetama.

12. Tati Hartati selaku nasabah PT Akusindo Assetama.

13. Saiful Umar selaku nasabah PT Akusindo Assetama.

14. Aan Yulianto selaku nasabah BTN Syariah Cabang Pasar Minggu, Jakarta Selatan.

15. Heriawan selaku nasabah BTN Syariah Cabang Pembantu Fatmawati, Jakarta Selatan.

16. Muhammad Faris Baay selaku nasabah BTN Syariah cabang pembantu Bojong Sari, Sawangan, Depok.

\section{HASIL DAN PEMBAHASAN}

Didirikan pada tahun 2014 PT Akuisindo Assetama yang berkedudukan di Beltway Office Park Tower B Lt 5, TB Simatupang, Jakarta Selatan adalah sebuah Perusahaan yang bergerak pada bidang Jual Beli properti yang salah satu produknya adalah jual beli tanah dengan hak membeli kembali, yang menjadi dasar Utama mengapa PT Akuisindo Assetama membuat produk tersebut, adalah untuk menghindari riba. Selain alasan tersebut, kelebihan dalam jual-beli dengan hak membeli kembali salah satunya adalah karena prosesnya yang cepat, dan juga bagi perusahaan hal ini lebih menguntungkan dikarenakan lebih aman karena secara hak, hak nya sudah berpindah dari nasabah ke perusahaan dan dikarenakan hak yang sudah berpindah tersebut umumnya nasabah akan lebih berhati-hati dalam melakukan jual beli dengan hak membeli kembali, dan pastinya akan menghindari untuk tidak melakukan wanprestasi. 


\section{JUAL BELI DENGAN HAK MEMBELI KEMBALI DALAM PANDANGAN HUKUM ISLAM}

Dalam menjalankan bisnis keuntungan merupakan hal yang perlu di dapatkan agar perusahaan dapat berjalan secara keberlanjutan. Dalam mendapatkan keuntungan tersebut secara umum ada dua cara yang bisa dilakukan yaitu menekan biaya dan menambah pendapatan. Semakin rendah biaya maka akan semakin menambah keuntungan, begitu pula semakin bertambah pendapatan juga akan menambah keuntungan. Akan tetapi yang perlu diperhatikan dalam mendapatkan keuntungan adalah tidak boleh melakukan praktik yang bersebrangan dengan hukum syariah. ${ }^{9}$

Praktik jual beli dengan hak membeli kembali secara syariah sudah tertuang pada fatwa DSN (Dewan Syariah Nasional) MUI (Majelis Ulama Indonesia ) No 94, Akan tetapi fatwa tersebut mengkhususkan obyek jual beli hanya pada sertifikat berharga syariah. Adapun obyek jual beli pada penelitian ini adalah properti atau tanah dan rumah. Dengan kata lain, jual beli dengan hak membeli kembali dengan tanah dan rumah sebagai obyeknya belum ditetapkan halal haramnya oleh DSN MUI. ${ }^{10}$

Untuk mendapatkan gambaran dan pendapat syariah mengenai jual beli tanah dengan hak membeli kembali ini, penulis melakukan indepth interview/ wawancara dengan beberapa pakar dan praktisi keuangan syariah. Adapun hasil dari indepth interview/ wawancara dengan beberapa pakar dan praktisi keuangan syariah adalah sebagai berikut: ${ }^{11}$

Terdapat beberapa alternatif akad yang bisa dilaksanakanpara pakar syariah memberikan beberapa alternatif dan contoh akad yang dapat digunakan untuk memenuhi kebutuhan pihak-pihak yang bertransaksi dalam jual beli dengan hak membeli kembali ini. Beberapa alternatif akad yang diberikan yaitu: ${ }^{12}$

1. Bai' Wafa

Menurut Misno, Bai' Wafa menjadi alternatif yang selalu muncul dalam pembahasan jual beli dengan hak membeli kembali. Hal ini dikarenakan karena bai' wafa menjadi praktik yang familiar baik praktik

\footnotetext{
9 Wawancara dengan Misno, Tanggal 23 Agustus 2017, di STEI TAZKIA Bogor

10 Ahmad Azhar Basyir. Asas-asas Hukum Muamalah(Hukum Perdata Islam. (Yogyakarta: Perputakaan FH UII, 1993) 110.

11 Algifari. Statistik Induktif untuk Ekonomi dan Bisnis, (Yogyakarta: Akademi, 2003). 92.

12 Ali Muhammad Daud. (2002).Hukum Islam: Pengantar Ilmu Hukum dan Tata HukumIslamdi Indonesia. Ed 6. Cet 10. (Jakarta: Raja Grafindo Persada) 63.
} 
pada masa kini (salah satunya di negara Malaysia) maupun praktik pada masa terdahulu. Sedangkan menurut hasil wawancara dengan Ismail, selain karena praktiknya yang sudah umum dilaksanakan dalam pelaksanaanya juga relatif mudah dan tidak ribet, sehingga secara praktik bisa lebih efisien.Akan tetapi menurut Mughni, mayoritas ulama kontemporer tidak memperbolehkan adanya praktik bai' wafa ini. ${ }^{13}$

2. Rahn

Rahn atau gadai menurut Mughni, dalam pembahasan fiqih muamalah termasuk kedalam akad Tabarru'. Dalam akad Tabarru' maka yang dikedepankan adalah niat Charity atau sosial saling membantu, oleh karena itu dalam praktiknya di larang untuk mengambil manfaat dari pelaksanaan akad tersebut. Khusus dalam akad Rahn maka Marhun atau barang yang di gadaikan tidak boleh di manfaatkan. Jika membahas Rahn maka praktik awalnya barang yang di gadaikan adalah sebagai jaminan atas pinjaman yang diberikan, hal ini dapat kita ketahui dalam QS AlBaqarah ayat 283, Mayoritas ulama memperbolehkan akad Rahn, akan tetapi sebagian ulama tidak memperbolehkan apabila obyek Rahn nya adalah tanah. ${ }^{14}$

3. Al bay' ma'al wa'd bi al shira'

Al bay' ma'al wa'd bi al shira' ini merupakan adopsi dari fatwa DSN MUI No 94 tentang Repo SBS. Akan tetapi pada fatwa DSN tersebut obyek jual belinya adalah Sertifikat berharga syariah, sedangkan pada penelitian ini obyek jual belinya adalah tanah dan rumah.Mayoritas pakar membolehkan akad ini, akan tetapi harus mengedepankan prinsip kehati-hatian karena rentan terjatuh pada praktik bai' innah. ${ }^{15}$

4. Akad jual beli yang dilanjutkan sewa menyewa (sale and lease back).

Praktek Akad jual beli yang dilanjutkan sewa menyewa (sale and lease back) menurut Mahbubi, secara umum diperbolehkan akan tetapi dengan tetap menerapkan prinsip kehati-hatian. Secara umum Jual Beli Sewa menyerupai transaksi sale and lease back. Dalam skema perbankan konvensional menurut Rahmatiyaningsih seorang Praktisi Pembiayaan Properti, transaksi ini mirip dengan transaksi top-up pembiayaan rumah,

${ }^{13}$ Almaarif Sayyid Sabiq. Fiqh al-Sunnah,Terj. Kamaluddin dan Marzuki. (Bandung: AlMa'arif, 1987) 116.

14 Amir, M. Taufiq. Dinamika Pemasaran; Jelajahi dan Rasakan, (Jakarta: PT Raja Grafindo Persada, 2005) 90.

${ }^{15}$ Antonio, Syafi'i, Muhammad. Bank Syariah: Dari Teori Ke Praktik, (Jakarta: Gema Insani, 2001) 43. 
akan tetapi dalam perbankan syariah Indonesia hampir tidak ada praktik yang menyerupai Model ini. Mayoritas pakar membolehkan akad ini, akan tetapi harus mengedepankan prinsip kehati-hatian karena rentan terjatuh pada praktik bai' wafa $^{16}$

\section{JUAL BELI DENGAN HAK MEMBELI KEMBALI DALAM PANDANGAN HUKUM POSITIF}

Perjanjian jual beli dengan hak membeli kembali diatur dalam pasal 1519 Kitab Undang-undang Hukum Perdata yang berbunyi "Kekuasaan untuk membeli kembali barang yang telah dijual diterbitkan dari suatu janji, dimana si penjual diberikan hak untuk membeli kembali barang yang dijualnya, dengan mengembalikan harga pembelian asal, dengan disertai penggantian yang disebutkan dalan pasal 1532. Jual Beli diperbolehkan asal saja dibuat secara terpisah dari perikatan jual beli, dan yang paling terpenting dalam hukum perdata adalah kesepakatan kedua belah pihak yang mengikatkan diri. Jual Beli Sewa diperbolehkan dikarenakan secara hukum hak atas tanah tersebut sudah berpindah dengan adanya perjanjian jual beli, dan apabila ada kontrak sewa yang dibuat antara pembeli dan penjual merupakan suatu hal yang secara hukum sudah sah dikarenakan dibuat berdasarkan kesepakatan antara kedua belah pihak. ${ }^{17}$

Perjanjian Jual beli tanah dengan hak membeli kembali dengan Perjanjian pinjam-meminjam, tentunya berbeda. Perbedaanya dimulai dari perjanjian awalnya. Perjanjian jual beli pengikatannya jual beli jadi secara hukum sudah berpindah haknya dan kemudian untuk membeli kembalinya di dalam perjanjian terpisah berbeda dari perjanjian jual belinya, sementara untuk perjanjian pinjam meminjam hak nya tidak berpindah dan hanya diberikan hak tanggungan saja. ${ }^{18}$

Secara khusus aspek hukum yang harus di pertimbangkan dalam melakukan perjanjian ini adalah sama dengan melakukan perjanjian pada umumnya yaitu sesuai dengan pasal 1320 KUHPerdata, yaitu: ${ }^{19}$

\footnotetext{
16 Arikunto, Suharsimi. Prosedur Penelitian: Suatu Pendekatan Praktik, edisi Revisi. (Jakarta: PT Raja Grafindo Persada, 2002) 12.

${ }^{17}$ Ascarya. Akad \& Produk Bank Syariah. (Jakarta: PT Raja Grafindo Persada, 2008) 81.

${ }^{18}$ Wawancara dengan Imam Cahyono, tanggal 15 Agustus 2017, di Kantor notaris Imam Cahyono Depok.

${ }^{19}$ Ayub, Muhammad. Understanding Islamic Finance, (Jakarta: Gramedia Pustaka, 2009) 77.
} 
1. Sepakat mereka yang mengikatkan diri, artinya antara penjual dan pembeli harus sepakat terlebih dahulu untuk melakukan transaksi jual beli.

2. Kecakapan dalam membuat perjanjian, dalam hal ini kedua belah pihak yang akan mengadakan perjanjian harus cakap secara hukum, artinya tidak dalam pengampuan/ curatele, dan juga penjual harus pihak yang mempunyai hak untuk menjual tanah/ bangunan tersebut.

3. Suatu hal tertentu, maksudnya disini adalah objek yang diperjanjikan dalam hal ini adalah tanah dan bangunan, disini pembeli harus jeli terhadap kepemilikan akan tanah/ bangunan tersebut, penjual merupakan orang yang berhak untuk menjual.

4. Suatu sebab yang diperkenankan, dalam hal ini perjanjian ini adalah hal yang diperboleh kan artinya tidak ada yang dilanggar, jadi harus dilihat bahwa tanah/bangunan tersebut merupakan tanah milik penjual dan bukan tanah sengketa.

Para pihak yang melakukan jual beli harus memahami juga hak dan kewajiban Penjual dan pembeli diantaranya adalah: ${ }^{20}$

1. Hak dan kewajiban Penjual

Adapun hak dari penjual sama seperti perjanjian jual beli pada umumnya yaitu penjual berhak untuk meminta pembayaran atas tanah/bangunan yang dijual kepada pembeli, sementara kewajiban dari Penjual adalah menyerahkan tanah dan bangunan yang dijual tersebut, dan dikarenakan ini perjanjian jual beli dengan hak membeli kembali, kewajiban Penjual lainnya adalah harus membeli kembali tanah dan bangunan tersebut sesuai dengan kesepakatan yang sudah dibuat baik itu jangka waktunya maupun jumlah pembayaran pada saat pembelian kembali. $^{21}$

2. Hak dan Kewajiban Pembeli

Adapun yang menjadi hak Pembeli adalah menerima penyerahan terhadap tanah dan bangunan dari penjual, dikarenakan perjanjian ini jual beli dengan hak membeli kembali maka Pembeli juga mempunyai hak untuk menerima pembayaran pada saat pembelian kembali yang besar dan waktunya sesuai dengan yang diperjanjikan. Sementara kewajiban

\footnotetext{
${ }^{20}$ Buchari Alma. Manajemen Pemasaran dan Pemasaran Jasa. (Bandung: Alfabeta, 2004) 34.

${ }^{21}$ Departemen Agama RI. Al-Qur'an dan Terjemahannya. (Semarang: PT. Karya Toha Putra, 1998) 231.
} 
dari Pembeli adalah membayar dengan Lunas Tanah dan Bangunan yang sudah di beli kepada penjual.

Selain hak dan kewajiban penjual dan pembeli, perlu diperhatikan juga akibat hukum dari perjanjian jual beli. Akibat hukum yang terjadi pada saat perjanjian jual beli dengan hak membeli kembali diantaranya:

1. Terjadi perpindahan hak atas tanah/bangunan tersebut dari Penjual kepada Pembeli.

2. Pembeli berkewajiban membayar atas tanah dan bangunan terebut.

3. Pembeli berhak untuk menerima tanah dan bangunan tersebut.

4. Penjual berhak menerima atas pembayaran tanah dan bangunan tersebut.

5. Penjual berkewajiban menyerahkan tanah dan bangunan tersebut.

6. Penjual berkewajiban membeli kembali tanah dan bangunan tersebut.

\section{HASIL OLAH DATA KUISIONER ANP PADA MODEL YANG ADA}

Hasil pengolahan data dari para responden dalam hal pemilihan model yang paling tepat terangkum dalam gambar 4.3 di bawah ini. Dari gambar 4.3 tersebut dapat dilihat bahwa terdapat variasi perbedaan dari para Responden. Tiga responden memberikan hasil Jual Beli Sewa sebagai model pilihan utama, sedangkan selebihnya menganggap Rahn dan Jual Beli sebagai pilihan utama mereka.

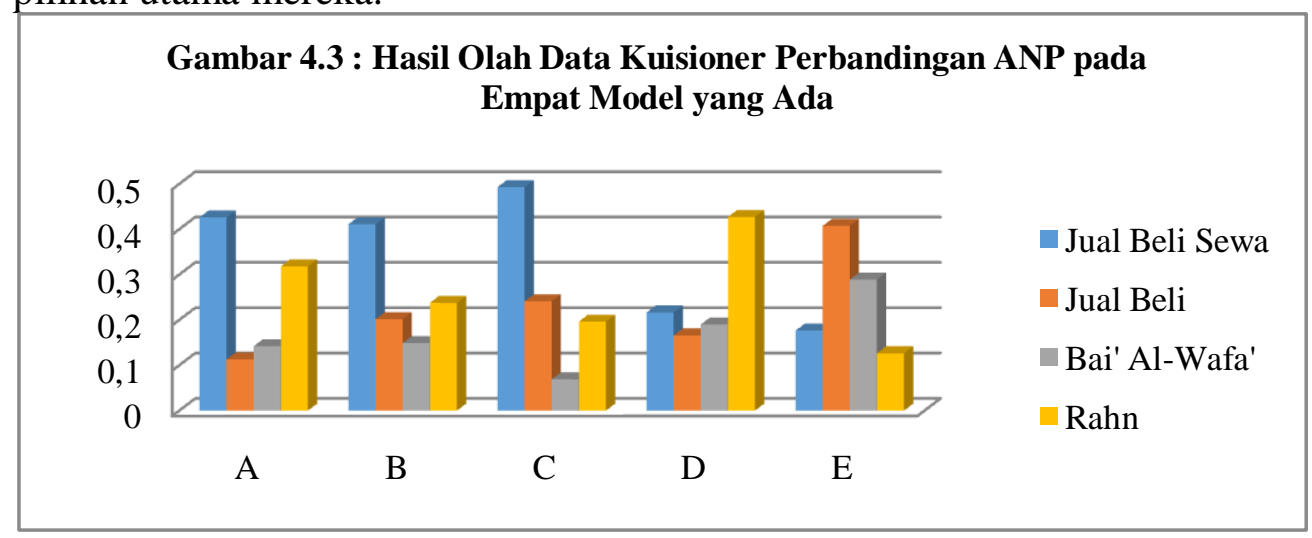

Secara umum perbedaan pendapat antar responden tidak terlalu signifikan, hal tersebut di cerminkan oleh tingkat rater agreement yang cukup tinggi yaitu sebesar 0,333333. Nilai rater agreement tersebut mencerminkan bahwa secara umum para Responden memiliki pendapat yang relatifsama dengan beberapa perbedaan yang tidak terlalu signifikan.

Secara rata-rata urutan prioritas dari keempat model yang ada dapat dilihat pada gambar 4.4 di bawah ini. Dari gambar 4.4 tersebut dapat kita 
lihat bahwa secara rata-rata Jual Beli Sewa menjadi model yang paling utama dengan nilai prioritas sebesar $(0,34)$. Pada urutan kedua adalah Rahn dengan nilai prioritas $(0,26)$. Adapun pada urutan ketiga dengan nilai prioritas yang tidak terpaut jauh yaitu Jual Beli dengan nilai prioritas $(0,23)$. Sedangkan pada urutan prioritas yang keempat yaitu Ba'i Al-Wafa' dengan nilai prioritas $(0,17)$.

Dapat kita lihat bahwa perbedaan nilai prioritas rata-rata antara Jual Beli Sewa sebagai urutan pertama dan $B a^{\prime} i$ Al-Wafa' sebagai urutan terakhir memiliki perbedaan nilai prioritas yang cukup jauh. Sedangkan di sisi yang lain perbedaan nilai prioritas rata-rata antara Rahn sebagai urutan kedua dan Jual Beli sebagai urutan ketiga tidak terlalu jauh. Dengan kondisi nilai rater agreement sebesar 0,333333 , maka perbedaan nilai prioritas yang tidak terlalu jauh antara Jual Beli dengan Rahn menjadi hal yang tidak perlu terlalu diperhitungkan. Dengan kata lain kita dapat memilih baik Jual Beli maupun Rahn sebagai alternatif kedua, dan akan sangat baik apabila didasari dengan mempertimbangkan maslahat dan mudharat yang ditimbulkan sesuai dengan kondisi dan situasi kasus perkasus. ${ }^{22}$

\section{KESIMPULAN}

Berdasarkan pemaparan diatas dapat disimpulkan bahwa jual Beli dengan hak membeli kembali jika ditinjau dari Hukum Positif (perdata) sudah diatur dalam pasal 1519 Kitab Undang-undang Hukum Perdata yang berbunyi "Kekuasaan untuk membeli kembali barang yang telah dijual diterbitkan dari suatu janji, dimana si penjual diberikan hak untuk membeli kembali barang yang dijualnya, dengan mengembalikan harga pembelian asal, dengan disertai penggantian yang disebutkan dalan pasal 1532". dan juga dalam membuat perjanjian tersebut harus sesuai dengan Pasal 1320 KUHPerdata, tentang syarat sah nya suatu perjanjian.

Jual Beli dengan hak membeli kembali jika ditinjau dari Hukum Islam memang tidak diatur secara eksplisit, baik itu dalam Al-Qur'an dan Hadits, pada praktik nya di Indonesia Praktik jual beli dengan hak membeli kembali secara syariah sudah tertuang pada fatwa DSN MUI no 94. Akan tetapi fatwa tersebut mengkhususkan obyek jual beli hanya pada sertifikat berharga syariah.Adapun obyek jual beli pada penelitian ini adalah properti atau tanah

\footnotetext{
${ }^{22}$ Haris Herdiansyah. Wawancara, Observasi, dan Focus Groups: Sebagai Instrumen Penggalian Data Kualitatif.
} 
dan rumah, Mayoritas pakar membolehkan akad ini, akan tetapi harus mengedepankan prinsip kehati-hatian karena rentan terjatuh pada praktik bai' innah.

Adapun hasil dari Implementasi Produk jual beli dengan Hak membeli kembali PT. Akuisindo Assetama, Dekomposisi permasalahan untuk pilihan model menghasilkan empat Model. Empat model tersebut yaitu, Jual Beli Sewa dimana jual-beli dengan hak membeli kembali dengan adanya tambahan akad sewa menyewa, Jual Beli yang merupakan jual-beli dengan hak membeli kembali dengan terlepasnya antara jual-beli pertama dan kedua, Ba'i Al-Wafa' yang menggunakan bai'wafa, dan Rahn yang menggunakan akad rahn. Implementasi di PT. Akuisindo Properti Assetama yang berpengaruh adalah Jual Beli Sewa, karena mengandung syariah.

\section{DAFTAR PUSTAKA}

Abdul Rasyid Saliman. et al. (2008). Hukum Bisnis Untuk Perusahaan: Teori dan Contoh Kasus, Kencana Prenada Media Group, cet. Ke 4.

Abdurrahman al-Jaziri. (1990). Kitab al-Fiqh Ala Madzahib al-Arbaah, Juz I, Beirut: Daaral-Kutb al-Ilmiyyah,.

Afifuddin dan Beni Ahmad Saebani. (2000). Metodologi Penelitian Kualitatif, Bandung

Ahmad Azhar Basyir, (1993). Asas-asas Hukum Muamalah(Hukum Perdata Islam). Yogyakarta: Perputakaan FH UII.

Algifari. (2003). Statistik Induktif untuk Ekonomi dan Bisnis, Yogyakarta: Akademi.

Ali Muhammad Daud. (2002).Hukum Islam: Pengantar Ilmu Hukum dan Tata HukumIslamdi Indonesia. Ed 6. Cet 10. Jakarta: Raja Grafindo Persada.

Almaarif Sayyid Sabiq. (1987). Fiqh al-Sunnah,Terj. Kamaluddin dan Marzuki. Bandung: Al-Ma'arif.

Amir, M. Taufiq. (2005) Dinamika Pemasaran; Jelajahi dan Rasakan, Jakarta: PT Raja Grafindo Persada.

Antonio,Syafi'i, Muhammad. (2001). Bank Syariah: Dari Teori Ke Praktik, Jakarta: Gema Insani.

Arikunto, Suharsimi. (2002). Prosedur Penelitian: Suatu Pendekatan Praktik, edisi Revisi.Jakarta: PT Raja Grafindo Persada.

Ascarya. (2008). Akad \& Produk Bank Syariah. Jakarta: PT Raja Grafindo Persada. 
Ayub, Muhammad. (2009).Understanding Islamic Finance, Jakarta: Gramedia Pustaka.

Buchari Alma. (2004). Manajemen Pemasaran dan Pemasaran Jasa. Bandung: Alfabeta.

Departemen Agama RI. (1998). Al-Qur'an dan Terjemahannya. Semarang: PT. Karya Toha Putra.

Efendi, Yazid, M., (2012). Fiqh Muamalah dan Implementasinya dalam Lembaga Keuangan Syari'ah. Yogjakarta: Logung Pustaka.

Haris Herdiansyah. (2015). Wawancara, Observasi, dan Focus Groups: Sebagai Instrumen Penggalian Data Kualitatif. Jakarta: Rajawali Pers.

Hasan, Ali, M. (2004). Berbagai Macam Transaksi dalam Islam. Jakarta: PT Raja Grafindo Persada.

Hasan, Iqbal. (2006). Analisis Data Penelitian dengan Statistik. Jakarta: Bumi Aksara. Jakarta: Kalam Mulia.

Karim, Adiwarman, (2003). Bank Islam (Analisis Fiqih dan Keuangan). Jakarta: IIIT Indonesia.

Kasmir. (2002). Manajemen Perbankan. Jakarta: Raja Grafindo Persada.

Khallaf, Wahab. (1994). Abdul, Ilmu Ushul Fiqh. Semarang: Dina Utama.

M. Ali Hasan.(2003). Berbagai Macam Transaksi dalam Islam (Fiqh Muamalah). Jakarta: PT. Raja Grafindo Persada.

M. Hasbi Ash Shiddieqy. (1997). Hukum-hukum Fiqh Islam, Semarang: Pustaka Rizki Putra.

Masadi, A., Ghufron. (2002). Fiqih Muamalah Kontekstual, Jakarta: PT Raja Grafindon Persada.

Mukhamad Saekan. (2010). Metodologi Penelitian Kualitatif. Kudus: Nora Media Enterprise.

Nasution. (2003). Metode Penelitian Naturalistik Kualitatif. Bandung: PT Tarsito Bandung.

Nasution. (2006). Metode Research (Penelitian Ilmiah). Jakarta: PT Bumi Aksara.

Nazir, Mohamad. (1988). Metode Penelitian. Jakarta: Ghalia Indonesia

Noeng Muhajir. (2000). Metodologi Penelitian Kualitatif Edisi IV. Yogyakarta: Rake Sarasin.

Ramulya, Idris, Moh. (1995). Asas-Asas Hukum Islam. Jakarta: Sinar Grafika.

Sabiq, Sayyid. (2000). Fikih Sunnah. Jakarta: Cakrawala Publishing.

Sayyid as-Sabiq. (1987). Fiqih Sunnah, cet. Ke-1, alih bahasa. Khamaluddin dan A. Marzuk Bandung. 
Sayyid, Al-Imam, Muhammad, Ibn Ismail, Al-Kahlani, Al-Sun'ani.Subul Al-Salam Sarh Bulugh Al-Maram Minjami' Adilati Al Ahkam. Kairo: Juz 3, Dar Ikhya' Al-Turas Al-Islami. Shofwan, Ahmad.

Sugiyono. (2013). Metode Penelitian Kuantitatif, Kualitatif, dan $R \& D$, Bandung: Alfabeta.

Suhendi, Hendi. (2002). Fiqh Muamalah: Membahas Ekonomi Islam. Jakarta: PT Raja Grafindo Persada.

Syaifudin Azwa. (2001). Metode Penelitian. Yogyakarta: Pustaka Pelajar.

Syalibi, Ahmad. (1988). Sejarah dan Kebudayaan Islam; Imperium Turki Usmani.Yogyakarta: Graha Ilmu.

Taqiyuddin Abi Bakar al-Husaini. (1990) Kifayat al-Akhyar, Juz I. Semarang: Toha Putra.

Tony Wijaya. (2013). Metodologi Penelitian Ekonomi dan Bisnis: Teori dan Praktik. Utama.V, Jakarta: Rineka Cipta.

Veithzal Rivai dan Andria Permata Veithzal. (2008). Islamic Financial Management : Teori, Konsep, dan Aplikasi Panduan Praktis Untuk Lembaga Keuangan, Nasabah, Praktisi, Dan Mahasiswa. Jakarta: Raja Grafindo Persada.

Yahya, Muhtar dan Rohman, Fatchur. (2006). Dasar-Dasar Pembinaan Hukum Fiqh Islam. Bandung: Al-Ma'arif.

Yanggo, Tahido, Huzaemah. (1997). Pengantar Perbandingan Madzhab. Jakarta: Logos Wacana Ilmu.

Yatim, Badri. (2003). Sejarah Peradaban Islam. Jakarta: PT. Raja Grafindo Persada. 